ANGYAL Ádám

\title{
AZ INNOVÁCIÓ TÁRSADALMI FELELŐSSÉGE
}

A szerzố kutatásának legfóbb eredménye egy új fogalom megalkotása: az innováció társadalmi felelôssége. Az innováció a gazdasági élet fontos és nélkülözhetetlen eleme. Ez az általános megközelítés jellemzi az innovációs folyamatok kutatását is. Nem vitatva az innovációk hasznosságának igazságát, ebben az írásban kiszélesíti ezt az általánosan használt és szigorúan korlátozott megközelítést. Tapasztalatai és kutatásainak eredményei szerint két új megközelítéssel gazdagítja az innováció fogalmát. Az elsố az innovációk feltétlen hasznosságával kapcsolatos. Az innovációk veszélyesek is lehetnek. Megemlítve az atombombát, a DDT rovarirtót vagy a szintetikus kábítószereket, világos lehet, hogy mit tart veszélyes innovációnak. Az innováció fogalmának értelmezésében egy további új területre utal. Nemcsak a gazdaságban, de a társadalmi élet egészében ismertek az innovációk. A szocializmus, ez a jelentốs és végsó soron sikertelen társadalmi innováció a legjelentôsebb példa a sikertelen társadalmi innovációra. Napjainkban is találkozni lehet kétes hozadékú társadalmi innovációkkal. Írása néhány példát említ a mai veszélyes kimenetelú intellektuális kezdeményezésekból is.

\section{Kulcsszavak: innováció, társadalmi felelôsség, társadalmi veszélyek}

Az innovációról az a vélekedés, hogy az jó, hasznos. Általánosan elfogadott, hogy az innováció a növekedés motorja és a jólét záloga. ${ }^{1}$ A fejlődés elengedhetetlen feltételének tekintik. Elsôsorban a gazdasági folyamatokban, az üzleti érvényesülésben vélik az innovációt elsôrendű tényezőnek. A növekedés, a fejlódés, a haladás, általában a gazdaság alapvető céljainak elérése nem nélkülözheti az innovációt.

Kevés szó esik az innováció néhány jelentős problémájáról. Ismertek például az olyan innovatív kezdeményezések, folyamatok, amelyek károsak. Ezt többnyire nem azonnal és nem közvetlenül lehet érzékelni. A káros vagy felhasználhatatlan innovációk a gazdaságban gyorsan kimutatják foguk fehérjét. Nem növelik a nyereséget, esetleg veszteséget okoznak vagy az üzleti értelemben vett hatékonyságot rontják. Ha azonban nem szorítkozunk csupán a gazdasági hatásokra, hanem szélesebb látószögben vizsgáljuk a megújulási kezdeményezéseket, akkor napjainkban elsôsorban a természeti környezeti veszélyek ötlenek a szemünkbe. Az innovációs folyamatok környezetveszélyeztető hatását úgy szokás kifejezni, hogy a megújított folyamatok, ha nem közvetlenül károsak, de gyakran nem fenntarthatóak. A fenntarthatóság foglalja össze azokat a hatásokat, amelyek - gyakran csak igen hosszú idő alatt - bizonyítják, hogy az innováció valóban hasznos volt.

Ezen a nyomon elindulva a környezetre gyakorolt hatást ki lehet egészíteni egy további összefüggéssel. Értelmezni lehet a társadalom egészére, az emberiségre gyakorolt innovációs hatásokat is. Ezek - akárcsak a természeti környezeti fenntarthatatlanság - sokszor nem kívánatosak, nem tekinthetốk a haladás szolgálatának. Paradox módon a gazdaság, az üzleti közösségek számára elsődlegesen hasznos innovációkról is kiderülhet, hogy a természeti és társadalmi környezet - environment és milieu - számára veszedelmesek.

Nem szokás az innovációk szélesebb értelemben vett kockázatairól sem értekezni. A kockázatot gazdasági összefüggésben elsősorban fejlesztési és befektetési értelemben vizsgálják. A kockázati tôkének nevezett innovációfinanszírozás például kifejezetten az alacsony valószínúségú vagy bizonytalan megtérülésú tervekhez köthető. Ez az írás ezen túllépve az innováció társadalmi kockázatait és veszélyeit is értelmezi. 


\section{Az innováció értelmezésének kiterjesztése}

$\mathrm{Az}$ innováció fogalma eredendően a gazdasági folyamatokhoz kapcsolódva jött létre. Az elsố innovációteoretikusok a XX. században túntek fel. A klasszikus innovációs szakirodalom² termékek, technológiák (eljárások), piaci múveletek és szervezetek (szervezés) vonatkozásában értelmezte a fogalmat. A termékek körét már a szolgáltatásokkal is kiegészítik. Az innováció létét az említett területeken az újdonság, a termelési tényezók ,új kombinációja” testesítette meg, azaz bizonyította. ${ }^{3} \mathrm{Ez}$ az eredeti, lényegében az üzleti gyakorlathoz kötődő megközelítés mára elavult, de a lényeges összefüggéseket jól szolgáló értelmezést tesz lehetővé. A termelési tényezók köre az említettek mellett például sok más új elemmel bóvült. Ilyenek az emberi eróforrások, a logisztika, a kapcsolati és információs hálók, a vezetés stb. Egyre jelentősebb mértékben tartják termelési tényezőnek a természeti és társadalmi környezetet, a jogrendet, a politikai viszonyokat, a technológiai környezetet, az erkölcsi normákat stb. Mindez azonban nem változtatta meg azt az alapvetést, hogy az innovációt a gazdasági folyamatok környékén szokás értelmezni.

Az innováció általában megújulást, eredetien újnak számító megoldást jelent. Innovációnak tekinthetô továbbá az ismert tényezôk új kombinációja, elrendezése, alkalmazása. Innováció továbbá az ismert, de nem alkalmazott vagy elfeledett módszerek újraélesztése. Európa számára például innováció volt a puskapor feltalálása némely kísérletező kedvű barátok által még akkor is, ha Kínában már évszázadok óta tudták a titkát és használták is.

Maga az újdonság kidolgozása, a megújulás is menedzselési, kivitelezési támogatást kapott. Kidolgozták, hogyan lehet innovatívnak lenni. Ennek szakaszai általában a következók:

1. inspiráció, megérzés, ötlet, felfedezés (megvilágosodás),

2. saját, az érvényességet és alkalmazhatóságot bizonyító kutatás és fejlesztés,

3. mások hasonló célú kutatási és fejlesztési eredményeinek alkalmazása,

4. tudásbevonás mint szabadalmak, licencek, knowhow megoldások, szellemi termékek és jogosultságok beszerzése és alkalmazása: ennek egyik, napjainkra jellemzô módszere a hálózatos innováció (crowdsourcing ${ }^{4}$ ), a kollektív, egymástól szervezetileg független, de kapcsolódó fejlesztés, a világháló korábban elképzelhetetlen dimenziókat adott a hálózatosodásnak, meggyorsítva és kiterjesztve azt az egész glóbuszra, a crowdsourcing (az innováció tömegbe való kihelyezése) és a tömeges innováció többi típusa (co-creation, civil science) a nyílt innovációk fejlettebb formáit képviselik, azok minden hasznával és kockázatával együtt: jellemzóje a csoportos, egymás eredményeit kölcsönösen hasznosító fejlesztés,

5. előállító, megvalósító technológiák kiválasztása, elókészület a megvalósításra (hardware és software kiválasztás/fejlesztés, ingatlan és gyártóberendezések biztosítása, anyag és energia kiválasztása szerződési és jogi feltételek kidolgozása stb.),

6. felkészülés az előállításra, megvalósításra, alkalmazásra, prototípus elóállítása, kísérleti alkalmazás megszervezése, az ezekhez kapcsolódó lépések kidolgozása (logisztika, design, tesztek, eljárás standardok stb.),

7. piaci megvalósítás, eladás, alkalmazás, hasznosítás (marketing, bevezetési stratégia),

8. kapcsolódó folyamatok (kommunikáció, oktatás, értékelés-elemzés, jogvédelem stb.).

Erre a folyamatra jellemző, hogy az egyes elemek, lépések akár összevonhatók, elhagyhatók, átugorhatók, felcserélhetôk és kiterjeszthetôk. Az innováció-előállítás fentebb részletezett folyamatának elsố négy tétele a szellemi eredmény, az eredeti vagy viszonylagos újdonság, az új kombináció megalkotása. A második négy elem a piaci hasznosulás, a megvalósulás, az alkalmazás folyamatát részletezi, bár ezek átfedhetik egymást.

Összességében tehát az üzleti gyakorlatban az innovációt két tényezóvel jellemezhetjük: ${ }^{5}$

1. újdonság, viszonylagos újdonság, eredeti vagy származtatott megoldás, a tényezók új kombinációjának kiötlése és kidolgozása,

2. hasznosítás, bevezetés, megvalósítás, alkalmazás, ami piaci értelmezésben egyszerúen eladást is jelenthet.

Az üzleti, azaz piaci hasznosítású innovációkat néhány tulajdonság jellemzi. Így az eladás, alkalmazás után a vevőnek nem kell feltétlenül együttmúködnie az innovátorral. A megvásárolt javakat, szolgáltatásokat, eljárásokat maga is használhatja rendeltetésszerúen. Ez jelenti a teljes piacképességet. Az eladó innovátor ugyanakkor törekedhet az üzleti haszon fokozása érdekében a kapcsolat fenntartására, akár kényszerpályák kijelölésével is. Ezért alkalmaznak olyan módszereket, melyek a további együttmúködést serkentik. Ilyenek például a garanciafeltételekhez kötött együttmúködés, a fejlesztési opciók, az avulási figyelmeztetések, a kizárólagos szervzelés és javítás stb. 
A megvalósult innovációk további jellemzője, hogy annak eredménye megismételhető, sokszorosítható, azaz legfeljebb jogi kizárólagossága, védelme teremthetô meg (bár az informatikai jelenlét ezt is módosíthatja). Az innovált termék, szolgáltatás, megoldás jellemző sajátossága továbbá az egyediség, azaz más termékektől, szolgáltatásoktól, eljárásoktól való megkülönböztethetôségük.

Az eredeti gazdasági (üzleti) innováció értelmezésen érdemes túllépni. Felismerésünk lényege az, hogy az innováció fogalmát kiterjesztjük a környezetre is. A természeti környezettel kapcsolatos innovatív megoldásoknak már hatalmas az elismertsége. Ezekkel kapcsolatban igen gazdag szakirodalom, kutatási feldolgozás alakult ki az utóbbi évtizedekben. A társadalmi innováció fogalmi köre azonban nem terjedt el és nem tisztázódott. Jelenségeit politikusok, társadalomtudósok, történészek, szociológusok szokták értelmezni. Mindezek az elemzók azonban többnyire nem innovációs hatásként értékelik, elemzik a változásokat. Mi most erre irányítjuk a figyelmet.

\section{Az innováció mint a változás sajátos esete}

Az innovációkat folyamatelemzési értelemben változásnak, változtatásnak lehet tekinteni. Akárcsak minden változtatásra, úgy az innovációra is érvényesnek tekinthetốk a változási tipológiák. Ezek lényegében a következóképp értelmezhetôk.

A változások intenzitása szerint megkülönböztethetốk az inkrementális és a radikális változások. Az inkrementálisak lassabban, általában iteratívan, gyakran csak korlátozott mértékben hatnak, zajlanak. Jellegzetes iteratív változás például a próbálkozás. A radikális változtatások gyorsan, átfogóan, többnyire egész folyamatot, rendszert, terméket illetően, mondhatni alapvetően érvényesülnek. A radikális változásokat forradalminak is nevezik. (Ez alkalommal eltekintünk a reklámiparban használatos „forradalmian új” elnevezéstôl, amit akár valamely zoknira is értelmeznek.) Ezek a változások a szóban forgó tényezók egészére terjednek ki.

A változások jellege szerint megkülönböztethetôk teljesen eredeti, addig nem ismert vagy nem használt, esetleg elfeledett módszerek, eljárások kifejlesztése. Ilyennek tekinthetô például az ipari forradalom nagy folyamata. Ennek lényege és alapja az erógépek feltalálása és alkalmazása. Kezdetben a gôz, majd a robbanó-, végül a villamos motorok kifejlesztése és elterjesztése jelenti az ipari forradalom lényegét. Hasonló folyamat zajlik napjainkban az infokommunikációban, amely az informatika, a távközlés, a hálózatosodás, a digitalizá- lás, a mikroelektronika, a szilíciumalapú „emlékezés” és még néhány technikai megoldás együttes eredménye. Ezeket szokás diszruptív, a korábbi megoldásokkal gyökeresen szakító, sốt azokat kiszorító innovációnak is nevezni. A motorizáció kiszorította a lóvontatást, és a gépek megalkotása nyomán a kézimunka nagy részét. Az infokommunikáció miatt megszúnt a papíralapú tudáshordozás kizárólagossága. Megjelent a széles körú valós idejú információáramlás és -feldolgozás, ami olyan korábbi, zseniális innovációs eredmények, mint rádió, televízió és telefónia háttérbe szorulását, helyettesítését eredményezte.

A változások másik jellegzetes típusa az olyan ismeret, tudás, amely már rendelkezésre áll, de még nem hasznosították, alkalmazták, vagy most új területeken valósul meg. Ezek tipikus példái az alapkutatási eredmények, melyeket többnyire nem is a közvetlen hasznosíthatóság érdekében adnak közre. Közismert a hadiiparral kapcsolatos innovációk civil alkalmazásának széles köre, mint például a GPS általános és ingyenes használata. Éles szemú innovátorok felismerik az alkalmazásában rejlő lehetőséget, és megszületik a piacképes innováció.

A változások kiterjedése szerint megkülönböztethetốk a szóban forgó termék, szolgáltatás, folyamat egyes elemeinek változtatására irányuló törekvések. Ezeket moduláris (részleges, alrendszereket vagy elemeket érintô) változásnak nevezzük. Ha a változás az öszszetevő elemek, alrendszerek szerkezetét, összetételét, arányait, egymással való kapcsolatát érintik, akkor azt strukturális változtatásnak lehet tekinteni. Ezeket lehet új kombinációknak is tekinteni.

A változásokfogadása szerint is megkülönböztethetjük azokat. Általános tapasztalat a változásokkal szembeni személyi, szervezeti és intézményi (bürokratikus) ellenállás, az alkalmazások késleltetése. Közismert az innovációsmenedzser-igény. Ez azt jelenti, hogy minden fejlesztésnek szüksége van az innovátorok mellett támogatókra, akik az alkalmazást szervezik. Ezek hiányában a legjobb fejlesztésekkel is előfordulhat, hogy sokáig nem kerülnek a piacra, hasznosításra. A megvalósuló innovációk befogadása, érvényesülése lehet rohamos, de lehet döcögôs és elhúzódó is. Érdemes megemlíteni a korábbi megoldások kiszorítását, azaz érdekeket sértő innovációkat. Ezek klasszikus példái a géprombolók, akik munkalehetőségeiket féltve támadtak az új berendezésekre.

Nem szokás az innovációk hasznosságát vitatni. A hasznosság értékelését célzó eljárások, mint például az értékelemzés, háttérbe szorultak. Helyettük többnyire a hozamokat szokták értékelni. Az innováció arra az alapvetésre épül, hogy a megújulás hasznos, előrevi- 
vô folyamat. Az innováció mérésére irányuló sokféle megoldások alapvetően a gazdasági értékelhetôséget célozzák meg. ${ }^{6}$ Ezek lehetnek input-, ráfordítás- és outputalapú számítások. Az innovációs mutatók széles rendszere, átfogó felmérésekkel és adathalmazokkal alátámasztva képet ad a tevékenység apró részleteirôl és hatásairól is.

Az üzleti világban erre több igen jó mérôszám is ismert. Alapvetô a profit és az újdonságok részesedése az értékesítési bevételból. Olyan innovációt többnyire nem támogatnak az üzleti szereplők, amelyek legalább számukra nem hasznosak. Ismertek egyébként olyan kezdeményezók is, akik nemcsak, hogy nem tudtak innovációjukkal eredményt elérni, de kifejezetten veszteségeket okoztak vagy szenvedtek. Ő́k azonban a gazdasági élet hatalmas asztalán legfeljebb morzsák. Tevékenységüket a tudománytörténet, a vállalkozói legendák és a furcsaságok könyvei ôrzik.

Ellentétben az üzleti világ radikális viselkedésével, a nem gazdasági területeken az innovációk káros volta messze nem derül ki egyértelmúen és viszonylag gyorsan. Elsősorban a természeti és társadalmi környezetet érintố innovációk esetében figyelhetô meg jelentôs többnyire csak közvetve és távlatosan - értelmezhető károkozás. Jelen dolgozat ezt a felismerést értelmezi a társadalmi változásokkal kapcsolatos innovációkat elemezve.

Az innováció tipologizálása a társadalmi változások innovatív szemléletú értékelése során különös jelentôségú. Ha például a magyar és más posztszocialista országok átfogó rendszerváltozásait értékeljük, melyek a huszadik század utolsó évtizedében történtek, akkor felvetődik, hogy mindezek innovációk voltak-e. Véleményünk szerint - figyelembe véve a korábban vázolt fogalmi meghatározást - innovációként, megújulásként is értelmezhetôk. Természetüket tekintve ezek radikális változások voltak, mert a rendszerjellemzók lényeges elemeit érintették. (Még akkor is egyaránt radikálisnak lehet tekinteni a változásokat, ha a forradalom Csehországban bársonyosan, Romániában pedig véresen valósult meg - hogy utaljunk a média és az elemzók kedvelt szóhasználatára.)

A társadalmi innováció értelmezéséhez tartozik, hogy sok esetben itt is ismertek, megnevezhetók az innovátorok, a kezdeményezók, a „feltalálók”, akik a változásokat generálták. A kilencvenes évek társadalmi rendszerváltási folyamatában is jól azonosíthatók a szellemi vezérek - az innovátorok -, akik kezdeményezók és ideológusok ${ }^{7}$ is voltak. Az említett innováció, vagyis ezen országok társadalmi rendszerének radikális megváltoztatásában közös elem volt, hogy nem teljesen eredeti javaslatokkal álltak elő, hanem ismert, másutt már alkalmazott módszerek (piacgazdaság, parlamenti demokrácia, többpártrendszer, állami és köztulajdoni monopóliumok jelentôs visszaszorítása, decentralizáció, központi gazdaságirányítás és tervezés megszüntetése, hatalmi ágak szétválasztása stb.) alkalmazását kezdeményezték. Erre az esetre lehet értelmezni az „új kombináció” tényét, ami maga is innovációnak felel meg. Az újdonságot az adott országok tényleges politikai gyakorlatával való radikális szakítás és a piacgazdaságokban, a kapitalizmusban már alkalmazott társadalom- és gazdaságszabályozási módszerek adaptálása jelentette.

A társadalmi innovációk közül példának említhető a jogrendszer, a jogi gondolkodás két jelentős fejlesztő lépése. Ezek nélkül a mai gazdasági jog és üzleti élet nem múködne. Az egyik a természetes személyek felelősségének monopóliumát törte meg és „feltalálta” a jogi személy fogalmát. A klasszikus jogelvek szerint ugyanis felelősség csak természetes személyt (embert) terhelhet. Ez ma is így érvényesül egyes jogágakban, mint többnyire a büntetôjog és családjog területén. Figyelemre méltó, hogy a természetes személyekhez kötődő személyiségi jogi kategóriákat is - részben értelmezték a jogi személyekre is. A jogi személyiség feltalálása és alkalmazása a jogrendben megvalósította a felelősség személytelenítését és áthárítását a jogi személyekre, azaz a szervezetekre. Ez az innováció lényegében megalapozta a szervezetekkel kötött szerzôdések mai rendszerének kialakulását.

A másik nagy jogi lelemény - mondhatni innováció - a korlátolt felelősség intézménye. Ez tette lehetővé olyan vállalkozások, társult szervezetek létrehozását, amelyek az alapítók, befektetốk, érdekeltek számára magánvagyonuk, megtakarításaik elvesztésének kockázata ellen megnyugtató védelmet, biztosítékot jelent. Ezek szerint a kockázat alapesetben csak a befektetések mértékéig terjed. A gazdasági élet, a tőzsde, a hitelezés, a szerződések, és lényegében minden gazdasági múvelet ezen elvek szerint zajlik. Az említett két jogi innováció az üzleti világban ma minden aktus alapját képezi.

$\mathrm{Az}$ államok is korlátolt felelősség alapján, vagyoni cenzusok (adófizetési és beszedési képesség) alapján látják el közfeladataikat. Hiába rögzíti például alkotmány vagy nemzetközi szerződés, esetleg politikai ígéret valamely feladat ellátását (lakhatás, nyugdíjellátás, egészségügyi és szociális szolgáltatás, iskoláztatás, szegénység felszámolása stb.), az államok ennek csak korlátozott mértékben, bevételeik erejéig (és politikájuk szerint) tesznek eleget. Miután a bevételek többsége az állampolgárok és szervezeteik jövedelméból képződik, így ôk az állami kockázat- és felelősségvállalás korlátozott felelősségú alanyai. Mindez kiterjed az ál- 
lami kötelezettségvállalásokra is, amelynek összefoglalója az országok költségvetése.

A felhozott példák arra utalnak, hogy a társadalmi haladás jelentôs lépései maguk is innovációs teljesítmények, folyamatok eredményeiként értelmezhetók.

\section{Veszély, kár, kockázat, bizonytalanság}

Az előzőekben tisztáztuk, hogy milyen jelenségeket, folyamatokat értünk innováció alatt. Annak érdekében, hogy egyértelmú legyen, mit is tekintünk káros innovációnak, néhány ezzel kapcsolatos fogalmat is értelmezünk, pontosítunk. Ez azért szükséges, mert a fogalmak keverednek, köznapi értelmezésükben gyakran pontatlanul, átfedően használják azokat.

Írásunk többek között az innovációs veszélyekról szól. A veszélyt elemzésünk szempontjából káros, a folyamat vagy jelenség alkotói, befolyásolói számára nemkívánatos következményként lehet számon tartani. E tekintetben egyaránt veszélynek lehet tekinteni a közvetlen és a járulékos hatásokat is. A tréfában gyakran emlegetett példa szerint, ha egy orvosi beavatkozás sikeressége mellett a beteg meghal, akkor e járulékos, mondhatni mellékes következményként a beavatkozás is értelmét veszti, vagyis a mútét igencsak veszélyes volt.

A veszélyt elóre érzékelhetó esélyes (káros) lehetôségnek értelmezzük. Részletezzük e meghatározás minden szavát. Az előreláthatóság azt jelenti, hogy az akciót megelőzóen már tudni lehet a veszély várható bekövetkezéséról, ez valószínúsíthetố is. Az esélyesség éppen a valószínúsíthetôséget jelenti. A veszélyben a bekövetkezésnek számottevő, a döntéshozók vagy az érintettek számára megfontolandó mértékú a valószínû́sége. A veszély mint lehetôség úgy értelmezhetô, hogy a folyamat kimenetele, lehetséges következményei közt az adott vélekedés - a veszély - is jelen van, mértéke pedig ugyancsak befolyásolhatja a döntéshozók és érintettek véleményét.

A kár, károkozás valamely akció, cselekedet következménye. A kár ellentétes a célokkal ${ }^{8}$ és nem kívánatos az elérhető eredmények, hatások szempontjából. A kár gyakran mint járulék, mellékhatás jelentkezik. E tekintetben nincs jelentôsége annak, hogy a kár elôre kalkulálható - ez a veszély - vagy mondhatni spontán következmény. Meglehetôsen gyakori, hogy a károk az elképzelések vagy a megvalósítások pozitív hatásait oly mértékben ellentételezik, hogy az egész akció összességében nemkívánatossá válik. Kár alatt elemzésünk értelmében nem csak a természeti (jórészt elkerülhetetlen) hatásokat kell érteni. A kár az innováció öszszefüggésében negatív vagy járulékos következmény, függetlenül az innováció eredeti céljától. A továbbiak- ban többnyire veszélyekról esik szó, amelyek azonban végkimenetelükben - a szerzô szubjektív vélekedése szerint - kárt okozhatnak.

Társadalmi összefüggésekben nehéz megítélni, hogy például a vallásosság károsabb-e, mint az agnoszticizmus vagy ateizmus. Ha azonban a vallás vagy valamely hit, nézet, ideológia terjesztése és gyakorlása erôszakos, kizárólagos, a hatalmi rendszer által elvárt módon történik, akkor bátrabban említhetjük a veszélyességet és a károkozást.

Az innováció kapcsán felmerül a kockázat, kockázatosság fogalma. Ezt szúkebb értelemben befektetési, megtérülési kockázatnak szokás értelmezni. Ha az innovátor tevékenysége nem hoz hasznot, nem jár valamiféle pozitív eredménnyel a megvalósító számára, akkor azt feleslegesnek, üzemgazdasági értelemben ráfizetésesnek lehet értékelni. A kockázat általában a bekövetkezési valószínúség alapján értelmezhetô. Ha az innováció kedvező hatásainak bekövetkezése eléri azt a szintet, amit az innovátor vállal vagy elvisel, akkor a fejlesztés megindítható. Jellemzô, hogy az innováció kockázatát nem a megvalósulás, befektetés megtérülési kockázatának értelmezik. Elsősorban az innovációt alkotó szellemi folyamatok kreatív szakaszában nem pénzügyi, hanem célelérési kockázat terheli az újítókat. Ötletük, kezdeményezésük kivitelezhetősége, hasznosíthatósága és a tágan értelmezett haszonhajtó lehetôsége jobban érdekli ốket, mint a megtérülés vagy a hozam esélyeinek financiális számbavétele. Ezt a jelenséget tágan értelmezett - értékteremtésnek is lehet tekinteni. $\mathrm{Az}$ innovátor szemében érték, ha elképzelése megvalósul, még akkor is, ha az gazdasági vagy környezeti értelemben esetleg káros.

Érdemes a bizonytalanság fogalmát is átgondolni az innovációval összefüggésben. A bizonytalanságot a nem kalkulálható bekövetkezési valószínúség és hatás együttesének fogjuk fel. A nem számíthatóság problémája sok tudós közt eleve kizárja az értékelést. Ôk úgy gondolják, hogy aminek a hatása, következménye vagy más jellemzói nem kvantifikálhatók, azok nem tekinthetók valóságnak, létezésnek és értékelhetố jelenségnek.

Érdemes rámutatni a sztochasztikus kapcsolódások, trendanalízis, megbízhatósági elemzések, korrelációk, szinergikus viszonyok, valószínúségek, összefüggés-elemzések és más, csak közvetve számszerúsító elemzési módszerek használhatóságára, amelyek a bizonytalanság kezelését is szolgálják. A számszerúsíthetôség képviselóivel továbbá szemben áll a kvalitatív és kvidditatív ${ }^{9}$ értékelés tudományos megalapozottsága. A kvalitatív értékelést is gyakran addig fejlesztik, amíg az kvantitatív minősítést nem kap. Így például a diákok 
tudását osztályzatokkal jellemzik, de ez korántsem alkalmas a valós emberi értékek megjelenítésére.

Azonban a bizonytalanság értelmezése sokak szemében a kvantitatív jellegú valószínúsíthetőség hiányát jelenti. A bizonytalansággal kapcsolatos fogalmak több más rokon szóhasználathoz is köthetôk. Ilyen a már említetteken túl a kockázatosság, a kétely, a változékonyság, a homályosság, a tájékozatlanság, a tudatlanság stb. (Az angol nyelv is gazdag a rokon szavakban, mint uncertenity, risky, doubt, turbulence, ambiguity, ignorance, misinformation stb.)

Az innovációk megvalósulásának jelentôs részére, különösen a korai szakaszokban, a bizonytalanság a jellemző. Sok feltaláló vagy kutató ismer fel jelenségeket, összefüggéseket, okságokat, a dolgok természetét, de nem akarja, vagy nem tudja tudását még hasznosítani. Egyszerúen örül a felismerésnek, és nem zavarja annak bizonytalansága. Az innováció azonban nemcsak a felismerést, hanem az alkalmazást, a megvalósítást is jelenti. A szellemi szakaszban meglévő bizonytalanság nem akadálya, legfeljebb fékezóje az innovációnak. Úgy is mondhatni, hogy kétség övezheti az alkotó folyamatok eredményességét, hasznosíthatóságát. Az innováció további szakaszai oszlathatják el a kételyt, éppen a megvalósítás lehetőségével.

\section{Veszélyes innovációk a történelemben}

Miután áttekintettük az innováció jelen írás szempontjából általunk elfogadott fogalmát, típusait és az innováció társadalmi hatásainak eddig kevésbé feldolgozott problémáit, rátérünk a konkrét társadalmi innovációs veszélyek értékelésére. A veszedelmes innovációk archetípusának az atombombát lehet tekinteni. Az elsô két bevetés előtt maguk az alkotók levélben fordultak az USA elnökéhez. Ebben kifejtették, hogy veszélyes lehet az atombomba. ${ }^{10}$ Ezzel kapcsolatban tudni érdemes, hogy korábban a tudósok még támogatták az atomfegyver-kísérleteket az USA elnökének írt levélben. Hat év múltán született egy újabb levél is. Szilárd Leó volt a kezdeményezô, aki tudomást szerzett Frederic Joliot Curie útján arról, hogy a nácik a háború végéig nem tudnak múködőképes atombombát készíteni. Megrettenve az amerikai atommonopóliumban rejlő veszélyektól, felkéri Einsteint, hogy állíttassa le a Manhattan-tervet. Túl későn: az 1945 áprilisában tett felhívást már Roosevelt nem tudta elolvasni: a levél kézbesítését követő napon elhunyt. Utóda, Harry Truman nem volt kíváncsi az emigráns német tudós aggályaira. Ezzel megpecsételődött Hirosima és Nagaszaki lakóinak sorsa.

Az atombomba vitathatatlanul jelentős innovációs eredmény, de az emberiség, a széles értelemben vett tár- sadalmi és természeti környezet számára rendkívül veszedelmes hatásait ismerhettük meg. Az atombomba és más tömegpusztító eszközök, mint további fejlesztések, nyomán a nukleáris, vegyi, biológiai és más fegyverek betiltása, korlátozása, felszámolása nagyon nehezen, lényegében sikertelenül valósult meg. Az emberiség nagyobb rettegésben, fenyegetettségben él, mint e harci eszközök kifejlesztése előtt. (Ma már akár nosztalgiával emlékezhetünk az elsô világháborúban alkalmazott mérges gázokra, mert napjainkban ezeknél ezerszer hatásosabb népirtó eszközök állnak rendelkezésre.)

$\mathrm{Az}$ atombomba, a vegyi és biológiai fegyverek jellemző példák a káros innovációkra. Gyakran emlegetik a DDT vegyi rovarirtó szert is, amely a második világháború utáni két évtizedben az egész világon elterjedt. ${ }^{11}$ Káros hatásait felismerve betiltották, de kimutatható maradványai még ötven év elteltével is megjelennek az élelmiszerláncban. Sajátossága, hogy minél magasabb egy élelmiszernek a láncolatban elfoglalt helye, annál nagyobb a maradvány koncentrációja. A fúben még alacsony, az élő legeló állatokban már magasabb, a tốkehúsban ismét még több és a feldolgozott fertőzött húskészítményben a legjelentősebb. Ma már ugyan ezek szintje régóta nem éri el a kritikus (egészségre ártalmas) értéket, de gyanítható - néhány vizsgálat utal is erre -, hagy az emberi szervezetben, néhány érintett körzetben még mindig kimutatható a DDT-származékok jelenléte.

Napjaink egyik legveszedelmesebb innovációs folyamata a kábítószerek, ezek között is a szintetikus szerek előállítása és terjesztése. A kábítószer-fogyasztás, és különösen a függóség társadalmi veszélyei erőteljesen növekednek. Hatásuk a primitív népektól a legmagasabb státusú és kvalitású csoportokra is kiterjed. A kábítószer hatalmas - illegális - jövedelemforrás, egyben közveszélyes, és a közösség számára igen költségesen kezelhető problémahalmaz. A kábítószerek előállítása és részben terjesztése ugyanakkor nem vitathatóan innovációk tömegét alkalmazza, hasznosítja.

Az innovációk nemcsak termékekben és szolgáltatásokban, hanem folyamatokban is szerephez jutnak. A környezetszennyezés két legjelentősebb forrása napjainkban a villamos áram előállítása, illetve a közlekedésszállítás. Mindkét terület - mindegyike több gazdasági ágazatot és hálózatokat foglal magában - történelmi léptékekben igen jelentős innovációk eredménye. Hasznosságuk vitathatatlan, elterjedésük általános. Ha azonban a bolygónk környezeti állapotát vizsgáljuk, a legnagyobb ember okozta károkat ezek a folyamatok eredményezik. Ezeket kiegészítik például olyan viszonylag fiatal iparágak, mint a múanyagipar és az elektronikai ipar környezeti veszedelmei. Mindezek - és még mások - együttes hatására a Földön az emberiség ökológiai lábnyoma ${ }^{12}$ 
nagyobb értékú, mint a rendelkezésre álló területek mértéke. (Az ember vagy egy adott terület népességének a természetre gyakorolt hatását egy hektárban kifejezett mutatószámmal, az ökológiai lábnyommal lehet leírni. Az ökológiai lábnyom az a terület, ami károsodás nélkül meg tudja termelni az aktuális életvitelünkhöz szükséges javakat (élelem, energia stb.). Az átlagos egy före eső ökológiai lábnyom 2,2 hektár, 2,5-szer nagyobb, mint 1961-ben volt.)

A károkozás kiterjed az emberek élóhelyéül szolgáló területek fizikai határain túlra is. Említsünk meg két példát erról. A mintegy hatvan éve tartó aktív ưrkutatás - ember alkotta eszközök megjelenése a Föld légkörén kívül - egyik következménye a körülöttünk lévő úr szennyeződése. Az emberiség hulladéka és annak felelőtlen kezelése a világóceánok és tengerek egyes területein érzékelhetôen rontották az ökológiai állapotokat. A haladás az említett esetekben a környezet jelentős veszélyeztetőjévé vált. Az ökológiai lábnyom alapján végzett számítások azt is mutatják, hogy többet fogyasztunk és nagyobb terhet rovunk a környezetre, mint ahogy az megújulni, sốt akárcsak változatlan állapotban fennmaradni képes. A folyamat lassú, a megfordítására, de csak a lassítására is tett törekvések eddig kevés eredménnyel jártak.

Korábban ismertté vált az a vélekedés, hogy a civilizáció folyamata nem más, mint az emberi magatartás folyamatos tökéletesedése, kifinomulása. ${ }^{13}$ Más vélekedések szerint a legmagasabb rendú és legutóbbi, az emberiség által elért állapotok tekinthetôk civilizációs eredményeknek. ${ }^{14}$ A környezettudatos gondolkodás tapasztalatai szerint a civilizáció fejlődésének egyik járuléka a természeti környezet rombolása, kihasználása, terhelése, veszélyeztetése. A természeti népek a környezetre nem jelentették a visszavonhatatlan változások veszélyét, ${ }^{15}$ ökológiai káros hatásuk szinte nem is volt. Környezeti értelemben a civilizáció, vagyis az emberiség innovációinak láncolata egyre veszedelmesebb és károsabb hatású.

Lépjünk túl a természeti környezet és az innováció kapcsolatának problémáin. A társadalmi, mondhatni civilizációs környezet tönkretételének is igen jelentős, az innováció definíciója szerint is értelmezhető példáit ismerjük. A rabszolgaságot, az emberkereskedelmet, a vallásháborúkat nem szokás innovációs eredményként értelmezni, de sok jellemző szerint azok voltak. Innovációnak tekinthetô a francia forradalom is, a velejáró terrorral együtt. Az egyik legjelentősebb társadalmi innováció a XX. század egyik legfontosabb történelmi eseménye, a szocialista társadalom kitalálása, megvalósítása, majd összeomlása. Idesorolható a nemzeti szocializmus és a fasizmus is, valamint a kulturális forradalomnak nevezett, és akár népirtásba is torkollott politika. A felsorolt példák valamennyien károsak, veszélyesek, és végsô soron rombolóak voltak. Nem szolgálták az emberiség haladását. Ezt annak ellenére ki lehet jelenteni, hogy sok pozitív, elvileg vagy korábban hasznosnak tûnt elem található valamennyiben. A politikusok, a történészek közt és a közgondolkodásban távolról sincs egyetértés ezekben a kérdésekben, így az értelmezés szubjektív, részleges és elfogult volta is vállalható.

\section{A közelmúlt veszélyes társadalmi innovációi}

A XXI. évszázadot az emberiség már két jelentős gazdasági világválsággal tapasztalta meg. Mindkettő mesterséges (kiagyalt) helyzet, és annak megvalósulása következtében állt elő. Az elsô a 2000. és az azt követô évek problémája. Jelentős pénzügyi összeomlás következett be néhány globális tőzsdei manôversorozat, az értéktelen kötvények (junk bonds) ${ }^{16}$ széles körú elterjesztése miatt. Ennek egyik mellékszála néhány csúcstechnológiában és az infokommunikációban érintett vállalatcsoport túlértékelése, tőzsdei villámkarrierje, majd kipukkanásnak is nevezett összeomlása. Mindezek a közvetlen és önmagában is káros pénzügyi hatásaikon túl munkahelyek százezreinek megszúnését, adóssághegyeket és elszegényedést generáltak. Ezek felszámolása a fejlődésre, fejlesztésre, jólétre fordítható eróforrások jelentôs részének igénybevételét követelte meg.

A másik említésre méltó gazdasági világválság a 2008. évi, ugyancsak pénzügyi indíttatású összeomlás. A folyamat mélyén a pénzintézmények túlzott hitelezési törekvése húzódott meg. Ez elsôsorban a befektetési, szúkebben az ingatlanpiacon jelentkezett. Az innovációnak is tekinthető szikra a meglévő hitelkihelyezési törekvésekben a hitelfedezet-értékelés módszerének változtatása volt. A hitelnyújtók ennek következtében olyan számításokat kezdtek alkalmazni, melyek a túlzottan kockázatos befektetések finanszírozását is lehetôvé tették, sốt támogatták. Az elvárható gondosság (prudencia) háttérbe szorult, sốt lényegében csalárd eljárásokkal helyettesítették. A felügyelő és a korábban biztonságot sugárzó jogrendszer ilyetén kijátszása önmagában is „ügyes” innovatív akció.

Magyarországon mindezt tetézte a világválság időszakával egybeesett, részben annak következményeként is értelmezhető devizaárfolyam-romlás (a forint értékvesztése). Ennek járulékos hatása a devizaalapon felvett, jelentős lakossági hitelek törlesztő kötelezettségének ugrásszerú emelkedése volt, ami számottevő nemfizetési, késedelmes fizetési és eladósodásalapú ellehetetlenülést váltott ki. A devizahitelezés jelentős 
innováció volt a magyar bankok körében. Azt sugallták a hitelfelvevônek, hogy a forinthitelezés terheinél jelentősen kedvezóbb kamatokat (teljes hiteldíjat) kell fizetni. A hitelfelvevók az addig többnyire lassú árfolyamromlás kockázatával nem számoltak (és nem is számolhattak).

Mindezek önmagukban - a többi társadalmi és gazdasági tényezô nélkül is - az érintettek körében válságokat, kényszermegoldásokat, vagyonvesztést, sôt akár a létfeltételek alapjának tekinthető lakhatási lehetőségek elvesztését is okozták. Járulékos kedvezőtlen, bár innovatív hatás az is, hogy a kormány a válságkezelés során korlátozta a forint konvertibilitását (magánszemélyek devizahitel-igénybevételének korlátozása hazai pénzintézeteknél), ami a nemzeti valuta iránti keresletet mérsékli. A magyar magánszemélyek mint forinttulajdonosok csak igen korlátozottan (túlszabályozottan) juthatnak devizahitelekhez, és ezzel versenyhátrányba kerülnek még a devizában kereskedő cégeknél.

Az említett válságokban több közös vonás is fellelhetô. Mindegyik globális volt, és azokat a szervezeteket és országokat is érintették, amelyeknek semmilyen értékelhető kapcsolatuk nem volt a kiváltó eseményekkel. Kiindulásuk egy-két vállalatbirodalom összeomlása volt, ami lavinaszerúen maga alá temetett egyre több érintett, majd végül szinte minden gazdálkodási szervezetet és folyamatot. Ebbe bele kell érteni a nemzeti költségvetéseket és a nemzetközi szervezeteket is. Mindkét jelenségben közös az is, hogy néhány pénzügyi vállalkozó, befektetőcsoport innovációja robbantotta ki nemcsak csalásokkal, hanem jogkonform ügyeskedéssel.

A válságsorozat felszínre hozott az egész világon, így jellemzően Magyarországon is, olyan szempontokat, melyek korábban csak érintólegesen voltak az elemzések témái. Ez az etikai megfontolások szerepe. Magyarországon kifejezetten érvényes ez. A devizaalapú eladósodás problémáit feszegető bírósági perekben a legfelsóbb igazságszolgáltatási testület kénytelen volt ítéletet alkotni. Ebben nem tudott pusztán érvényes jogi normákra támaszkodni, ezért elővett egy létezô, de alig használt, csak erkölcsileg alátámasztott szabályt, a tisztességesség követelményét. Világossá vált, hogy a jogi normák alapján képtelenség minden veszélyes magatartást, káros innovációt megfékezni. Erre az erkölcsök alkalmazása szolgálhat, azonban ennek gazdaságszabályozó hatása nagyrészt kidolgozatlan. Az etikai normák távolról sem rendelkeznek olyan kényszerítő és számonkérésre alkalmas eszközökkel, mint a törvények. Mindazonáltal az etikai megfontolások visszatérése a társadalmi szabályozásba akár önmagában is innovációnak („új kombináció”) tekinthető.
Ennek kapcsán megjegyezhetô, hogy az informatika és távközlés, konkrétan a világháló múködése is ellenáll a hagyományos szabályozási módszereknek. A jelenleg általános gyakorlat (és elmélet) szerint a közérdeket jogszabályokkal és azt érvényesíteni képes erószakszervezetekkel lehet érvényesíteni. Az internet azonban sem szabályokkal, sem rendőrséggel, katonasággal nem korlátozható. Napjaink egyik legjelentősebb, és az innovációs folyamatok többségében szerepet játszó, lényegében 1990 óta rohamosan terjedő internet veszedelmes lehetôségeinek korlátozására az említett hagyományos „kordában tartó”, közérdeket szolgáló módszerek (mint betiltás, büntetés, korlátozás, engedélyeztetés stb.) nem alkalmasak. Az etikai alapú megoldások, mint önkorlátozás, önszabályozás, nem elég hatékonyak. A világháló felborította, megtagadta a joguralom és erószak doktrínáit, nem engedelmeskedik azoknak. A kétségkívül korszakváltó innováció, az informatika hálózatos megjelenése az emberiség azon elvét, hogy van közérdek, és azt érvényesíteni kell, sok tekintetben megkérdőjelezte. Az informatizált társadalom szabályozása még várat magára.

Lássunk egy további innovációs problémát. Az Európai Uniós, és vele karöltve Magyarország is, sok tekintetben elzárkózik a génmódosított mezőgazdasági és állattenyésztési termékek előállításától és felhasználásától (az EU ennek egy részét nemzeti hatáskörbe utalja). Ugyanakkor a világ más részein, így vezető helyen az USA-ban a termelékenység növelése, és az ezzel kapcsolatos termelhetôség kiterjesztése során nagymértékben élnek a génmódosítás eredményeivel. Maga a génmódosítás jelentős tudományos és innovációs eredmény. A vita és az eltérô hasznosítási gyakorlat a távlati veszélyekkel és az ezekkel összefüggő kockázatokkal, a fenntarthatósággal függ össze. Ugyanakkor a génmúveletek pl. a humán immunológiában elterjedt és elfogadott beavatkozások. Nem kevés etikai érveléssel azon is vita folyik, hogy emberi mutációkat (klónokat) szabad-e egyáltalán előállítani, ami többek között a géntudományok fejlődésének egyik következménye. A genetikai múveleteket sokan veszedelmes beavatkozásnak tekintik a világ természetes rendjébe.

\section{Élố innovációs veszedelmek}

Nemcsak a közelmúlt termelt ki innovációs veszélyeket. Napjainkban sok olyan még élő innovációs kár telepszik az emberiségre, melyek egykor igen jó megoldásoknak, kreatív és konstruktív lépésnek, terméknek, technológiának túntek. A bevezetóben már említett környezetkárosítás maga is évezredes múltú, bár hatásai a huszadik században érték el azt a kritikus tömeget, 
amikor az egész emberiség létét kezdték veszélyeztetni. Érdemes korunk veszedelmes innovációi közül is néhányat megemlíteni.

Lényegében a második világháborút követô nehéz (újjáépítés, talpraállás) éveket követôen kezdetben tartósak voltak a fogyasztási cikkek, majd szélesebb értelemben is elterjedt az eldobhatóság innovatív üzleti gyakorlata. Ezt több ideológia is alátámasztotta. Ilyen volt például a termékélettartam rövidülésének, az erkölcsi avulás gyorsulásának nézete. Anélkül hogy a magyarázatokat részleteznénk, világos, hogy a gyártók számára az eldobhatóság, a rövidített élettartam piacnövekedést, eladhatósági többleteket jelentett. A tartósság, a hosszabb időtartamú megbízhatóság mint érték háttérbe szorult. Ugyanakkor e nézetek következtében jelentősen nôtt a világ anyag- és energiaszükséglete, és a feleslegessé vált javak miatt a hulladékkezelés költsége is. Jellemzố módon ma már egyes iparágak - így különösen az autóipar, a repülőgépgyártás - fejlesztéseinek fontos része a megsemmisülési hulladék újra felhasználhatóságának biztosítása. Az eladási kényszer szorítja az autógyárakat a termelés növelésére, a folyamatos verseny miatt a fejlesztésekre. Ezzel együtt szembe kell nézniük termékeik hatalmas hulladékképzô sorsával, és ennek kezelése további innovációkat igényel.

A hamar eldobható termékek forgalmazásához hasonló hatású a javítás helyett cserélés innovatív gyakorlata. Ennek következtében a meghibásodott alkatrészeket, sốt termékeket nem javítják még akkor sem, ha erre egyszerú és olcsó lehetôség nyílt volna. Ezt is több üzleti ideológia alapozza meg. Ennek részeként a gyártók és forgalmazók például azt közvetítik, hogy a javítás helyett az alkatrész, részegység cseréje - régi helyett új - kifejezetten a fogyasztó érdekeit képviseli. Mindez természetesen hat a karbantartási, javítási folyamatok változására, és különösképp a drágulásra, de növeli a környezetterhelést is.

A káros innovációk sorában ott találhatók a kreatív könyvelésnek, elszámolásnak nevezett, másutt adóoptimalizálásnak becézett megoldások. Ezek egy része egyszerú csalás, amit a jogrend értelmezni és büntetni képes. A kreatív könyvelés alapesetében a pénzügyi helyzetet kedvezóbbnek mutatják be, mint a valóság. Ehhez valós mutatókat és - esetenként akár jogszerúen manipulált - adatokat használnak. A kreatív elszámolások hátterében gyakran téves vagy torzított szabályértelmezések húzódnak.

A kreatív elszámolások jelentős része azonban valódi innováció. Megkeresni a jogrend kiskapuit, lehetôségeit, azokat kihasználni, akár a gazdasági tevékenységet az így feltárt lehetôségekhez igazítani, ez kétségkívül innovatív és a kezdeményezók számára jövedelmező tevékenység. Ennek részeként terjedtek el az offshore vállalkozások, adóparadicsomok, a múködési fố területtốl eltérô vállalkozásbejegyzések, a multidivizionális szervezeti rendszerek, a hálózatos jövedelemátrendezések. Svájc ily módon jelentôs folyami és tengeri flottával rendelkezik, noha nincs megfelelô vízi kapcsolata a külvilággal. Néhány változatukat a jogrend már korlátozza, úgymint a pilótajátékok, a befektetési szövetkezeteknek álcázott vagyonelsajátítások, értékesítési láncolatok. Nehéz az ezekkel szembeni jogi eljárási lehetôségek érvényesítése. Ennek oka az, hogy a jog maga nem képes minden lehetséges esetet szabályozni, erre legfeljebb nehezen számonkérhetô elveket lehet megalkotni. Ezek visszatartó ereje sekélyes. A határokon átnyúló folyamatok esetében a jog és eljárási rend különbözőségei is akadályozzák a jogelvek érvényesítését. Más oldalról az államok maguk is hajlamosak akár jogilag, akár erkölcsileg kétes ügyletekre és szabályozásra, így a kreatív megoldásoknak gyakran tálcán kínált alkalmakat. Az állami intézmények maguk is gyakran szabálysértően kreatívak, mondhatni innovatívak, és ezzel mintegy biztatást adnak a vállalkozóknak és magánszemélyeknek. Mindezek végső fokon a közérdek érvényesülésének csorbulását okozzák.

Figyelemre méltó innovációs tartalmú világfolyamat például a gyógyszer és a gyógyszernek (szabályozási okokból) sem minősülő kiegészítôk, tápszerek és hatóanyagok fejlesztése és piacának változása. Egyre több, hol természetes, hol kombinált hatóanyagú, de nem bejegyzett és engedélyezett, vagy akár nyilvántartásba se vett szer kerül kereskedelmi forgalomba igen élénk marketingtámogatással. Az orvostársadalom erőfeszítései ellenére ezek piaca bővül, naponta tûnnek fel új és újabb, valamint ősrégi(nek nevezett) szerek és módszerek, mint az igen kétes hírú távgyógyászat. Ezek egészségre gyakorolt hatása vitatható. $\mathrm{Az}$ orvostársadalom egy része hajlamossá vált a természetgyógyászat, homeopátia és más tradicionális módszerek alkalmazóit kóklernek, sốt kuruzslónak tekinteni. Vélekedésük bizonyítékául szolgálnak olyan „csodaszerek”, amelyek jó esetben semmilyen, de akár káros, fertôzố anyagokat is tartalmaznak. (Tudni lehet, hogy vannak teljesen legális és klasszikus gyógyszerek is, amelyekról kiderült, hogy káros, sốt veszélyes adalékokat tartalmaztak.)

A fentebb csak példának említett folyamatok mélyén innovatív kezdeményezések sejlenek fel. Ezekben ugyan nem mindig sikerült a kezdeményező, a felfedezô személyét azonosítani, de a korábbi üzleti és társadalmi szokások jelentős megváltozását lehet ta- 
pasztalni. Ez még olyan folyamatokra is jellemző, mint például a múveltség fogalmának és igényének változása. A hagyományos értelemben vett múveltség szokását lassan kiszorítja a tájékozottság iránti igény. Ennek hátterében a gyorsan megszerezhetố információk tömeges hozzáférhetôsége áll. Miután a múveltség piaci hasznosíthatósága szerény, így akár érthetô is lehet háttérbe szorulása. Ezt jelen sorok írója káros, sốt veszedelmes tendenciának értelmezi, akárcsak az oktatás, a kutatás és a fejlesztés támogatásának szerény, sôt torz, korlátozó változatait. Ezek mögött is olyan társadalomszervezési nézetek húzódnak, melyek lehetnek ugyan innovatívak, de - jelen sorok szerzóje szerint - károsak.

Egyre elterjedtebb a képzés, a tanulás megújítását szolgáló távoktatás. Ez a közvetlen tanári jelenlétet és felügyeletet, tudásátadást nem igénylő módszer sok tekintetben jól használható. Az oktatásban például a tesztalapú vizsgáztatás, számonkérés sikeres. Vannak azonban vadhajtásai is a távoktatásnak, az internetes képzésnek. Egyre több olyan lehetőség kínálkozik például bizonyítványok, oklevelek, diplomák megszerzésére, ahol valamely programozott tudásanyag ugyancsak programozott ellenôrzése alapján állítanak ki piacképes okiratokat. Ezek következtében akár úgy is lehet értékesnek túnő igazolásokat szerezni, hogy tanárral, oktatóval, magas minőségú tananyaggal nem is találkozik a jelölt, sốt még megfelelő elóképzettsége sincs. Ez az oktatási rendszer züllesztésének tekinthetó, bár kétségkívül jelentős innovációs teljesítményként is értelmezhetô.

Hajlamosak lehetnénk mindezeket egyszerúen a civilizáció természetes fejleményének tekinteni. Ha ez így van, akkor megállapítható, hogy a civilizáció folyamata esetenként nem az emberiség tágan értelmezett érdekeit szolgálja. Az üzleti, gazdasági érdekek általában jól azonosíthatók, mondhatni magukért beszélnek. A társadalmi, közösségi érdekek azonban nem rendelkeznek ilyen kézenfekvố tulajdonságokkal. Ezek nem beszélnek magukért, hanem igen gyakran fel kell azokat ismerni. A felismerés ${ }^{17}$ gyengéje azonban az, hogy sokan és sokféle közelítésben értelmezik a közérdeket, a közjót, sốt a társadalmi haladást. Lassú és háládatlan folyamat során alakul ki az a vélekedés, amit a társadalmi hasznosság, hatékonyság általános igényeit kielégíti.

A fentiekre ékes példa a jóléti társadalom koncepciója. Ez a doktrína úgy túnik, mintha megfelelne a közjóval kapcsolatos elképzeléseknek. Napjainkban sok vitatója akad. Elsősorban a fenntarthatatlanságát említik, másodsorban a korlátozott megvalósíthatóságát. Napjainkban Magyarországon szúkebb társadalmi vita észlelhetô egy jólétinek, szociálisan felelősségteljes- nek tekinthető nézet, a feltétel nélküli alapjövedelem bevezetése ügyében. ${ }^{18}$ Gazdasági és társadalmi érvek csapnak össze, amelyek bizonyítják, hogy a kétségkívül jó szándékú igyekezet megvalósítását távolról sem fogadja osztatlan lelkesedés. Ennek egyik oka az elképzelés mesterséges (azaz innovatív) természetének összeegyeztethetetlensége a mindennapi társadalmi folyamatokkal, tapasztalatokkal, igényekkel. ${ }^{19} \mathrm{Nem}$ állítható ugyanis, hogy a társadalmi folyamatok természetes (történelmi) rendjébe való beavatkozás az emberiség számára maradéktalanul hasznos lett volna.

Napjainkban Magyarországon figyelemre méltó közpolitikai kezdeményezések, innovációk tanúi és részesei lehetünk. Ezek egyike a hagyományos jogi alapvetések megtagadása, átértelmezése, élén az alkotmány átírásával és átértelmezésével. ${ }^{20}$ Egy jogtudós és gyakorló jogász az elmúlt négy év alapvetô hibájának nevezte, hogy megszúnt a tulajdonformák egyenlósége, az alaptörvényból ki is maradt a tulajdon szentségének tisztelete. Az Alkotmánybíróság (Ab) a hatalommegosztás és a joguralom legfóbb eleme az alkotmánymódosító hatalommal szemben, és be kell töltenie ezt a szerepét - jelentette ki, hozzátéve, hogy szigorú öszszeférhetetlenségi szabályokra van szükség (részlet). Megszúnt a tulajdonhoz való feltétlen jogosultság elve, mert az állam akár kártérítés nélkül is elvehet magántulajdont (magánnyugdíj-alapok konfiskálása). Megszúnt a visszamenôleges és az érintettekre kedvezôtlen szabályozás tilalmának jogi elve (meghatározott jövedelemfajták és szintek visszamenóleges adóztatása). Korlátozták az egyenlő adózás elvét, és különadókat vetettek ki indoklás szerint a teherviselő képességgel összhangban, de lényegében gazdaságpolitikai doktrínák alapján. Kettôs érveléssel zavarták meg az adózási gyakorlatot, amikor a személyi jövedelemadó lineáris voltának igazságossága mellett a reklámadó (és más adónemek) progresszivitásának igazságosságáról beszélnek. Megszúnt az ártatlanság általános vélelmezési kötelezettsége (a pénzintézetek egyes hitelmúveleteik esetében bizonyítani kötelesek jogszerú, átlátható és tisztességes magatartásukat). Megszúnt a jogsérelmek reparációjának általános lehetôsége (alkotmánybíróság hatáskörének csökkentése). Megszúnt a jogbiztonság, és ezzel veszélybe került a joguralom általános elve (esetleges és gyakran nem konzekvens jogváltoztatás, alaptörvény-módosulások, a jogi megalapozás - kodifikálás - nélküli elvek számonkérése, diszkriminatív jogalkotás és jogalkalmazás, jogi előkészítő munka és hatásvizsgálatok hiánya). Megszúnt a szerződések betartásának kötelezettsége (a devizahiteles problémák kezelésének tapasztalata), hogy a politikai ígéretek betarthatóságáról ne is essék szó. A jogszolgáltatás füg- 
getlenségének (fóképp a bírói szervezetek) erốteljes befolyásolása, szervezeti típusú kontrollja a mintának tekinthetó megoldások, eljárások alkalmazásának gyengülését okozta (alkotmánybírósági korábbi határozatok alkalmazásának eltörlése). Jelentôsen csorbult a hatalmi ágak szétválasztásának szokása és elvi igénye. Mindezeket - és másokat is - a legitimációs normák ${ }^{21}$ átírásának, átértelmezésének lehet tekinteni. Miután ezek nagy tömegben és rövid idő alatt jelentek meg és érvényesültek, így mindösszesen alapos okunk van jogrendszeri innovációként értelmezni a folyamatokat. A szakértók jelentős része mindezeket veszélyesnek, károsnak tekinti a társadalmi folyamatok egészére nézve.

További jelentôs innováció a gazdálkodásszabályozás területén észlelhető. A politikai szakzsargon és egyben a kezdeményezô személy unortodox gazdaságpolitikáról beszél, és ennek része a gazdaságirányítás ezzel összefüggó változása is. Eltekintve az unortodox szó helytelen használatától (helyesen heterodox vagy reform gazdaságpolitikáról kellene szólni), a gazdaságpolitikai innováció lényege közérdeknek nyilvánított törekvések elsốbbsége a gazdasági szereplôk érdekeivel szemben. Ez az elv nem új, de szemben áll a fejlett világ felfogásával, amely nem alárendelt, hanem mellérendelt viszonyt értelmez a közérdek és a magánérdek között. Az ismert piacgazdasági alapelvek szerint a gazdasági szereplók teljesítménye határozza meg egy ország lehetőségeit. Az unortodox doktrína szerint a gazdasági szereplőknek kell igazodniuk az állami célkitûzések megvalósításához. „A kormány gazdaságpolitikájával tehát nem az a baj, hogy nem hagyományos. A baj az, hogy (1) rossz a fókusza, mert a személyi jövedelemadó nem alkalmas a gazdasági növekedés újraindítására, (2) rossz eszközöket használ (amelyek sértik a jogbiztonságot, nem normatívak, durván beavatkoznak a piacgazdaság múködésébe) és (3) rosszul hajtja végre a programját (folyamatos rögtönzések, utólagos korrekciók, kétséges törvényhozási eszközök). És végül, ami az időtényezót illeti, nos, a program végrehajtása immáron második évébe lépett, az eredmények azonban egyáltalán nem látszanak, és a kilátások sem kecsegtetnek túl sok jóval." ${ }^{22}$ Ezt akár különadókkal, rendkívüli eljárásokkal, adóátrendezésekkel, kedvezménycsoportok piaci szereplók részére nehezen átlátható kialakításával stb. érik el. Az állam beavatkozási gyakorlata jelentősen túllépi a kiegyensúlyozott múködés megvalósításának igényét és lehetôségét. Az unortodox gazdaságpolitika olyan teljesen újszerú elvek és módszerek halmaza és mindezek alkalmazása, melyeket összességében társadalmi innovációnak tekintünk. Ennek káros voltát elemző szakértôi nyilatkozatok alapján vélelmezzük.
Napjaink hazai innovatív jelensége a társadalomszabályozás, melyet a miniszterelnök illiberális állameszmének hirdetett meg, ezen a néven vált közismertté. Ismét csak eltekintve a helytelen szóhasználattól (az illiberálist, ami korlátoltságot, szúkkörúséget, szolgasorsút jelent, keveri az antiliberálissal). Az illiberalizmus lényegében a nemzeti önérdek-érvényesítés (kormányfői zsargon szerint szabadságharc) dogmája. Ennek fontos része a kialakított társadalomirányítási gyakorlat, szokások, szerződések átalakítása a kormányzati elképzeléseknek megfelelően, de jórészt eltekintve azok hatásaitól, fenntarthatóságuktól és következményeitôl. Alapvető eleme a központi akaratérvényesítés (centrális erốtér), a manipulatív választási rendszerekkel stabilizált döntéshozatal, a korpásodás (ezt a múszót a korrupció + pazarlás öszszevonása alapján alkottuk). ${ }^{23} \mathrm{Az}$ illiberális államszervezési gyakorlatot bírálói maffiaállamnak is nevezik. Ennek egyik alapelve is ismert, akárcsak a tényleges maffia egyik törvénye. Az omerta, a hallgatás szabálya biztosítja a maffia erejét, azaz búneinek titkolását. Az illiberális államgépezet múködtető fő szabálya az együttszavazás (togethership) kötelme, mint a magyar omerta. Ez a kormánypártok tagjainak, és részben híveinek kötelessége, amely hálát (lehetőségeket) érdemel. Az együttszavazás kényszere attól függetlenül érvényesül, hogy a szavazónak mi az egyéni véleménye. Az illiberális államszervezés és -vezetés ugyanakkor innovatív, nemcsak megújuló, de sohasem tapasztalt elemeket is tartalmaz.

A társadalmilag veszélyes innovációk sorában egy európai uniós gyakorlatot is megemlítünk, amelynek sok hazai vállalkozó a kedvezményezettje. A kialakult, sok csatározásban végül elfogadott agrártámogatási gyakorlat - ezt tekintjük az innovációnak - a piacgazdaság alapvetô elveivel ellentétes. A mezőgazdaságban alkalmazott területalapú támogatásokról van szó. Ez lényegében azt jelenti, hogy a földtulajdonos vagy az általa nevesített használó, bérlő úgy jut számottevő jövedelemhez, támogatáshoz, hogy ezért nem kell piaci javakat elóállítania és azokat értékesítenie. Ez a jövedelemszerzésnek olyan változata, amely alapvetően ellenkezik a piacgazdaság normáival. A jövedelemért folytatott harc a piaci érvényesülés helyett adminisztratív eljárásokra, mint tulajdon- és haszonbérletszerzés irányul. A földvásárlás, a -bérlés, a -használat fontosabb jövedelemalkotó tényező, mint a gazdálkodás, földmúvelés, állattartás. Mindezeket Magyarországon részrehajló állami beavatkozás, jogsértések árnyékában valósítják meg. Ez az európai gazdaságszabályozási innováció a piacgazdaság egészére nézve veszedelmesnek mondható. 
Sorolhatók további példák azokra az élő jelenségekre, melyek kihasználva az innovációkat társadalmi veszélyeket is hordoznak. Végezetül csak az informatika által képviselt és megvalósuló búnözések példáját említjük. ${ }^{24}$ Ezek széles lehetőségeket nyújtanak nemcsak a jogsértésekre, de akár a társadalmi folyamatok szétzilálására, megbénítására is. Egy hackertámadás képes akár az adózás, a nyugdíjrendszer, a bankmúveletek, az állami adatnyilvántartás egészének megzavarására is, a védelmi beavatkozásokról nem is szólva. Az informatikai támadások azonban nem csak a csalási esélyek révén lehetnek veszedelmesek. Maga az informatikai társadalom olyan tömegú információt tesz hozzáférhetôvé és feldolgozhatóvá, mely a korábban alapelvként tisztelt társadalmi értékeket teszi nevetségessé. A személyiségi jogok, a szabadságjogok, az emberi jogok érvényesülése már lényegében nem biztosítható. ${ }^{25}$ Csak bonyolítja a helyzetet, hogy az információs szabadság és önrendelkezés elveit követve az állampolgárok és szervezeteik gyakran saját maguk hoznak létre olyan információkat az elektronikus térben, melyek felhasználását nem képesek ellenőrizni, így akár veszélyes is lehet számukra. A nagyszerú pénzügyi innováció, a bankkártyák elterjedése, a pénz nélküli fizetések előretörése például azzal a járulékos mellékhatással bír, hogy a tulajdonosokról sokkal több információt lehet megtudni, mint lehallgatásokkal vagy lesifényképezéssel. A társadalom nem készült fel ezeknek a mellékhatásoknak a kezelésére, tagjai kiszolgáltatottabbak, mint azt az innovátorok akarták.

\section{Összefoglalás}

Az innováció megítélésében többnyire a gazdasági öszszefüggések a meghatározók. Véleményem szerint ezt indokolt kibóvíteni. Elsôsorban a természeti és társadalmi környezetre gyakorolt innovációs hatások érdemelnek figyelmet. A természeti környezetben igen jelentős elméleti, tapasztalati és kutatási eredmények mutatják ki az innovatívnak tekinthető megoldások esetleges problémáit. Ezekre ebben az írásban ezért nem terjed ki a figyelem. A társadalmi környezet átalakulása, változása ugyancsak sok innovatívnak tekinthető folyamat eredménye. Ez az összefüggés eddig jelentős részben elkerülte a figyelmet. Írásunk célja erre rámutatni.

Az innováció - és általában a változások - elemzése során ritkán merül fel azok hasznosságának értékelési igénye. Figyelmünket azokra a problémákra irányítjuk, amelyek az innovációs veszélyek, károk csoportjába sorolhatók. A gazdaság területén az ilyen problémák gyorsan felszínre kerülhetnek, ezeket ugyanis a piaci szabályok, a nyereség iránti vágy határozottan koordinálják. Létezik a ,láthatatlan kéz”, az érdek, ami a veszedelmes innovációkat részben képes féken tartani. A természeti és társadalmi környezetben okozott károk azonban csak lassabban, közvetve, és nehezebben válnak nyilvánvalóvá. Nincs láthatatlan kéz, amely intene a veszélyekre. Az innovációs eredményeket a társadalom számára nem a szó szoros értelmében véve eladják, hanem sokkal inkább alkalmazzák. Az egyenes hatások pénzben csak számításokkal és közvetve mutathatók ki, közvetlen mérésük nem lehetséges. Vajon mennyivel ér többet a demokrácia, mint a diktatúra, és melyik tekinthetốbb társadalmilag veszélyesebbnek? A mérés helyébe kell lépnie a felismerésnek, a károkozás és veszélykeltés kimutatásának. Ha a társadalmi fejlődés egészét nézzük, akkor ennek részeként rá kell mutatnunk a jogi szabályozás és az erôszak alkalmazásának évezredes gyakorlata mellett más módszerek szükségességére is. Ilyen az erkölcsi, szokásjogi normák érvényesítése, a közérdek kifejezésének lehetősége és a holisztikus, a hatások egészét áttekintő innovációelemzés.

Írásom olvasata azt a vélekedést keltheti, hogy az innovációt, különösen a társadalmi (civilizációs) megújulást ellenezzük, kétkedve fogadjuk és veszélyesnek tartjuk. Ez abból következik, hogy elsősorban a veszélyekre akartuk felhívni a figyelmet. Az innovációt, ezen belül a társadalmi megújulást, a haladást, a civilizáció terjedését alapvetôen pozitívan értékeljük. Célom a mindezeket övező és kísérő némely veszedelmes jelenségekre is ráirányítani a figyelmet, mert ezek eleddig nem kaptak megfelelő értékelést.

\section{Lábjegyzet}

${ }^{1}$ Hámori B. - Szabó K.: Az innováció innovációja: új innovációtípusok a globális gazdaságban c. tanulmány bevezetô mondata: (Chandra et al., 2010; Mukherjee, 2011; OECD, 2007). Tanulmány a TÁMOP 4.2.1./B-09/1/KMR-2010-005. számú támogatási szerződés alapján A tudásalapú gazdaság Magyarországon, az innovációs szemlélet erősödésének és a K+Fteljesítmények növelésének feltételei címú kutatási alprojekt keretében készült. Munkapéldány 2014.

${ }^{2}$ Klasszikus innovációelméleti munkának általában Schumpeter, J. A. (1980): A gazdasági fejlődés elmélete. Budapest: a Közgazdasági és Jogi Könyvkiadó múvét, valamint tanai követőit és továbbfejlesztóit szokás érteni.

${ }^{3}$ OSLO manualwww.oecd.org/science/inno/2367580.pdf

${ }^{4}$ Hámori B. - Szabó K.: Az innováció innovációja: új innovációtípusok a globális gazdaságban

${ }^{5}$ Hámori B. - Szabó K. (szerk) (2012): Innovációs verseny. Esélyek és korlátok (nyomán). Budapest: Aula Kiadó

${ }^{6}$ Az innováció, szorosabban a kutatás és fejlesztés mérésével és értékelésével foglalkozik például Török Á. (2005): Competitiveness is research and development. Cheltenham: E. Elgar Publishing

${ }^{7}$ Ideológia alatt azt a szellemi hadat értjük, amely az elvek, hitek, nézetek, filozófiák egészét kötik össze a való világgal, a mindennapokkal. Az ideológia magyarázat arra, miként kapcsolódnak a nézetek és elvek a mindennapokkal. Az ideológiát szokás eszme- 
rendszernek is értelmezni, de mi ennél konkrétabb jelentőséget tulajdonítunk. Az ideológia adott esetben akár cselekvési programot is tartalmazhat.

${ }^{8}$ Ismertek károkozási célú tevékenységek, mint pl. a hatalom szempontjából a megdöntésére irányuló kezdeményezés vagy a telekárak lenyomása érdekében való területszennyezés. A szándékos károkozással elemzésünk további részében nem foglalkozunk.

${ }^{9}$ A kvidditatív értékelés fogalma nem terjedt el az elemzók között, ezért erre kis magyarázatot adunk. A kvidditatív tulajdonságok a valamely helyzetre, folyamatra jellemzó olyan meghatározó sajátosságok, egyediségek, melyek megkülönböztetik másoktól. Ezeket szokás paradigmáknak, esetleg filozófiáknak is (pontatlanul) nevezni. A kvidditás például azt jelenti, hogy a biológia tudományos eszköztára nem alkalmas társadalmi jelenségek megvizsgálására, mert azoknak más a kvidditása, azaz más paradigmák szerint értelmezhetók.

${ }^{10}$ Új Szó Archivum 2005. április 18.

${ }^{11}$ A DDT a diklór-difenil-triklóretán rövidítése, nagy hatású rovarméreg. Mivel az élő szervezetben felhalmozódhat, károsítja a környezetet. Magyarországon felhasználását az 1960-as évek végén betiltották. Magyarországon Hungária Matador, Nikerol, Holló, Burgol, Duolit, Permit néven gyártották és forgalmazták. A vegyületet - Gesarol, Guesarol, Neocid, Supracide Combi és Ultracid Combi néven - a második világháborúban a tífuszt, pestist, maláriát és sárgalázt terjesztô tetvek, bolhák és szúnyogok ellen használták. Elsőként - 1874-ben - Othmar Zeidler hozta létre a diklór-difenil-triklóretán (rövidítve DDT) névre hallgató vegyületet. Rovarölő tulajdonságát 1934-ben Paul Hermann Müller fedezte fel, s 1948-ban orvosi Nobel-díjat kapott érte. Wikipédia címszó

${ }^{12}$ www.zold_vallalat.hu

${ }^{13}$ Georges Duby - Robert Mandrou: A francia civilizáció ezer éve E-book

${ }^{14}$ A civilizáció „,a (mindenkori) társadalomfejlódés, illetve az anyagi múveltség legmagasabb foka, melyben a társadalmi-gazdasági alakulat, igényeinek megfelelően, szelektíven és módosítva magába olvasztja ... a korábbi korok eredményeit, tökéletesíti és továbbfejleszti óket. Ebben a tekintetben a civilizáció sokszor a társadalom szinonimájaként is használatos. Wikipédia címszó

${ }^{15}$ Ezt a problémát részletesen elemzi pl. Diamond, J. (2013): A világ tegnapig. Budapest: Typotex c. könyvében.

${ }^{16}$ A junk bonds fogalom eredetileg olyan fix hozamú kötvényeket jelentett, melyek lejáratakor a kibocsátó a vállalt kamatokat nem tudta teljesíteni, sốt akár a tókeérték (kötvényár) megtérítését sem vállalta. A pénzügyi válság után a junk bonds fogalmát kiterjesztették egyrészt a hamis befektetói ígérgetésekre, másrészt az eleve tudatosan, csalási szándékkal kibocsátott értékpapírokra és más pénzügyi instrumentumokra. www.investinganswers. com/financial_dictionary

${ }^{17}$ Angyal Á.: A felismerés és annak 23-féle támogatása. Vezetéstudomány, 2007/12.

${ }^{18}$ Bánfalvi I. (szerk.): 25-50-75 sültrealista ajánlat a magyar társadalomnak. Kézirat, 2013. 10. 13.

${ }^{19}$ Mihelics V.: A Beveridge-terv. Keresztes Kiadó, 1943. A Beveridge-terv volt az elsô, átfogó és (a mai magyar változathoz képest sokkal jobban végiggondolt) általános jóléti koncepció.

${ }^{20}$ Bárándy P.: Az alkotmányos rend helyreállításához rendbe kell tenni a jogállamrendet. Szegedma.hu 2014. 03. 11.

21

${ }^{22}$ Felcsuti P.: Mi a baj az unortodox gazdaságpolitikával? Magyar Narancs 2012. 03.16.

${ }^{23} \mathrm{Az}$ illiberális demokrácia nem alkalmas széles körú, tartós jólét megteremtésére - hangsúlyozta Budapesten tartott előadásában Joseph E. Stiglitz. A Nobel-díjas közgazdász szerint a gazdasági jólét megteremtéséhez tanuláson alapuló társadalom kell, amelyet csak liberális demokráciák tudnak garantálni. Stiglitz szerint az oroszországi modellre senkinek sem szabad sikerként tekintenie, az ugyanis az olaj- és gázbevételeken alapszik, nem pedig a jó gazdasági igazgatáson. Stiglitz, J.E.: A jóléthez tanuláson alapuló társadalom kell. Mandiner. 2014. 10. 10.

${ }^{24}$ Szathmáry, Z. (2012): Búnözés az információs társadalomban. Doktori értekezés. Pécs: Pécsi Tudományegyetem

${ }^{25}$ Orwell, G. (1989): 1984. Budapest: Európa Könyvkiadó. Ez a könyv vizionálta elôször az állampolgárok teljes körú ellenőrzését és ennek veszélyeit. 